\title{
Ruth Jensen
}

Institutt for lcererutdanning og skoleforskning

Universitetet i Oslo

E-post: ruth.jensen@ils.uio.no

\section{School leadership development: \\ What we know and how we know it}

\begin{abstract}
For several decades, researchers have studied school leadership development. However, the need exists for an updated literature review that pays heed to dominant research approaches, since the manner in which school leadership development is researched is consequential to our knowledge about the phenomenon. Thus, the aim of this study is to present a literature review that covers the period from the 1950s to the present, which examines what we have learned about school leadership development, identifies the dominant concerns and methodologies, and discusses the strengths and limitations of the existing research. Gunter and Ribbins' conceptualization of different knowledge provinces is used to support this analysis. This review demonstrates that school leadership development has expanded since the 1950s in terms of purpose, providers, pedagogies, content, and research approaches. In addition to discussing the strengths of the research, the analysis reveals various limitations in how school leadership has been investigated. For example, this review finds that the research does not sufficiently capture the fact that leadership development takes place across settings and over time, and that it involves interactions with several actors and pedagogical tools. The author argues that the theoretical and methodological approaches must be further developed in order to better capture these matters relating to school leadership development in the future.
\end{abstract}

Keywords: literature review, school leadership development, research traditions

\section{Sammendrag}

Forskere har over flere tiår studert skoleledelsesutvikling. Samtidig er det behov for en oppdatert vurdering av litteraturen som ser ncermere på hvilke tilnæerminger til forskning som dominerer. Dette er nødvendig fordi vår kunnskap om fenomenet påvirkes av hvordan utvikling av skoleledelse studeres. Artikkelen presenterer en vurdering av litteraturen på dette feltet fra 1950 og fram til i dag, og målet er å undersøke hva vi har lert om utvikling av skoleledelse, identifisere dominerende spørsmål og metodologiske tilnœrminger og diskutere sterke og svake sider ved eksisterende forskning. Analysen trekker 
veksler på Gunter og Ribbins rammeverk om ulike kunnskapstradisjoner og domener. Gjennomgangen viser for det første at utvikling av skoleledelse har ekspandert siden 1950 når det gjelder både formål, tilbydere, pedagogikk, innhold og forskningstilncerming. For det andre viser analysen at eksisterende forskning i mindre grad får fram hvordan ledelsesutvikling finner sted på tvers av ulike kontekster, over tid, og hvordan den inkluderer interaksjon mellom mange aktører hvor pedagogiske verktøy medierer utviklingen. Et hovedargument er at det er nødvendig å utvikle både den teoretiske og den metodologiske tilncermingen hvis vi skal gripe og begripe hvordan utvikling av skoleledelse skjer i fremtiden.

Nøkkelord: litteraturgjennomgang, skoleledelsesutvikling, forskningstradisjoner

\section{Introduction}

The need to promote a specific education in school leadership is recognized worldwide (Crow, Lumby \& Pashiardis, 2008). Several countries have established education requirements and programs in which students can earn credits and/or certifications before pursuing a career as a school leader. School leaders are also offered additional opportunities for further professional development via programs, networks, and teams wherein credits and/or certifications are not earned. This article refers to both types of development when using the term "school leadership development." This term refers to the preparation of aspiring leaders as well as to the further development of experienced school leaders.

From 1950 until the 1980s, the U.S. was virtually alone in educating school leaders. Beginning in the 1980s, countries around the world began to offer similar education programs in school leadership development. This article reviews what we have learned about school leadership development from the 1950s to the present. Various researchers have contributed to this area via reviews of research into aspects of school leadership development (for the USA, see: Davis et al., 2005; Murphy \& Hallinger, 1992, 1998; Murphy \& Forsyth, 1999; Chin, 2003; Hallinger, 2003; Grogan et al., 2009; for England, see: Brundrett, 2001; Bush \& Jackson, 2002; for Australia, see: Dempster et al., 2011). However, these reviews mostly refer to the researchers' own national contexts. As leadership development is an international phenomenon-at least as of the 1980s - there is a need to approach the literature from an international perspective. Thus, there is a need to conduct an updated review. There are many types of reviews (Grant \& Booth, 2009). Grant and Booth identified 14 review types and associated methodologies. This article can be conceptualized as a "literature review". ${ }^{1}$ 
The article is built on the assumption that what we know about school leadership development is influenced by how we have come to know it. Consequently, it is important to identify the utilized research approaches when interpreting the results of a study. Second, concerns regarding research into school leadership development are not always explicitly voiced. Thus, identifying these underlying concerns might be important when reviewing the field. Third, there is no guarantee that research on school leadership development keeps pace with the changes in how school leadership, as actual practices, develops. The way in which the actual practices develop may create new demands for the research, both theoretically and methodologically. Accordingly, there is as much need to identify weaknesses in the existing research approaches, as there is to highlight the strengths.

The purpose of the present article is to gain an enriched understanding of what we know about school leadership development and how we have come to know it and to use this understanding as a foundation for discussion regarding the implications for further research on school leadership development. To meet this purpose, various sources such as handbooks and scientific journals have been accessed. The aims of this article are to present a literature review of school leadership development research that encompasses a period from the 1950s to the present, to identify the dominant research methodologies and concerns, and to discuss the strengths and weaknesses of the existing research to encourage dialogues about further research on school leadership development. The following research questions have thus guided the analysis:

1. What have we learned about school leadership development since the 1950s?

2. What are the underlying concerns and dominant methodologies that might have affected the research?

3. What are the strengths and weaknesses of the research?

I have chosen to structure this presentation of research into school leadership development as follows: research beginning in the 1950s, research of the 1980s onward, and research from 2000 to today. These annual figures represent important changes in the trajectory of school leadership development. The focus of this article is delimited to what we know about the purpose of leadership development, the providers of development training, the dominant pedagogies, the content of training, and the organizational structures that have existed from the 1950s to the present; these factors are considered to be important premises and components of school leadership development. Accordingly, Gunter and Ribbins' (2003) typology of knowledge production is applied in the analyses of the underlying concerns that might have affected the research. Their typology is a comprehensive tool for mapping research on educational leadership. The present review does not use the whole framework. Rather, their framework is used as a supporting tool in the review process. 
This article is structured as follows. The subsequent section (Section 2) presents the analytic framework, while Section 3 describes the utilized review strategies. Section 4 communicates what we have learned about school leadership development from the 1950s to the present, and Section 5 discusses the strengths and weaknesses of the research. Finally, the conclusion is provided in Section 6.

\section{Analytic framework}

Three of Gunter and Ribbins (2003) six typologies of knowledge production have been selected to support the analysis of the present review, i.e. the "practices", the "processes", and the "provinces". ${ }^{2}$ According to Gunter and Ribbins, "practices" refers to the various actions made in real time. In this article, the term refers to the practices of school leadership development. The term may refer to school leadership development conducted on campuses, within or close to a workplace, or in a virtual space. The term "processes" refers to the research processes used to generate and legitimate what is known. The six knowledge provinces were developed through a production of "clusters around differentiated approaches to purpose” (Gunter \& Ribbins, 2003, p. 263). Moreover, they explain that "knowledge provinces mean what is being asserted as constituting the truth underpinning the intentions behind any leadership activity" (cf. p. 263). The leadership activities and practices to which this article refers involve school leadership development. The table below illustrates the various clusters of different approaches to purpose; this table was constructed based on publication outputs made in this field, which for this article included handbooks, chapters, and articles. The typology of the six knowledge "provinces" is presented in Table 1 below, which describes the specific concerns of the various provinces.

Table 1 The six knowledge provinces (Gunter and Ribbins, 2003, p. 133). 


\begin{tabular}{|c|c|c|c|c|c|}
\hline Conceptual & Descriptive & Humanistic & Critical & Evaluative & Instrumental \\
\hline $\begin{array}{l}\text { Concerned } \\
\text { with issues of } \\
\text { ontology and } \\
\text { epistemology, } \\
\text { and with } \\
\text { conceptual } \\
\text { clarification. }\end{array}$ & $\begin{array}{l}\text { Concerned } \\
\text { with } \\
\text { providing a } \\
\text { factual report, } \\
\text { often in some } \\
\text { detail, of one } \\
\text { or more } \\
\text { aspects of, } \\
\text { or factors, } \\
\text { relating to } \\
\text { leaders, } \\
\text { leading and } \\
\text { leadership. }\end{array}$ & $\begin{array}{l}\text { Concerned } \\
\text { with } \\
\text { gathering and } \\
\text { theorising } \\
\text { from the } \\
\text { experiences } \\
\text { and } \\
\text { biographies of } \\
\text { those who are } \\
\text { leaders and } \\
\text { managers and } \\
\text { those who are } \\
\text { managed and } \\
\text { led. }\end{array}$ & $\begin{array}{l}\text { Concerned to } \\
\text { reveal and } \\
\text { emancipate } \\
\text { practitioners } \\
\text { from injustice } \\
\text { and } \\
\text { oppression of } \\
\text { established } \\
\text { power } \\
\text { structures. }\end{array}$ & $\begin{array}{l}\text { Concerned to } \\
\text { measure the } \\
\text { impact of } \\
\text { leadership } \\
\text { and its } \\
\text { effectiveness } \\
\text { at micro, } \\
\text { meso, and } \\
\text { macro levels } \\
\text { of interaction. }\end{array}$ & $\begin{array}{l}\text { Concerned } \\
\text { with } \\
\text { providing } \\
\text { leaders and } \\
\text { others with } \\
\text { effective } \\
\text { strategies and } \\
\text { tactics to } \\
\text { deliver } \\
\text { organisational } \\
\text { and system } \\
\text { level goals. }\end{array}$ \\
\hline
\end{tabular}

The following explanations of the different typologies are used in the present article to support the analysis: research products with conceptual purposes are concerned with issues of ontology and epistemology as well as with conceptual clarifications or elaborations, while those with descriptive purposes are concerned with describing one or more aspects or factors related to school leadership development. Research products with humanistic knowledge purposes are concerned with gathering data and theorizing about the experiences and biographies of those involved in school leadership development, while those with critical purposes are concerned with revealing critical aspects of school leadership development. Finally, research products with evaluative purposes are concerned with measuring the impact of school leadership development and determining its effect, while those with instrumental purposes are concerned with identifying causal links between school leadership development and leadership in schools.

The following section describes the strategies used in the selection and deselection of sources for this review and illustrates how the review was conducted.

\section{Parameters of the review}

As a research field, school leadership development is an extensive and ripe topic. The aim of this article is not to provide an exhaustive review but to present and identify the dominant concerns and research methodologies that have existed since the 1950s. Knowing there are many types of review, the present review is a so-called "literature review" (Grant \& Booth, 2009) ${ }^{3}$.

The following strategies were used to select sources: The searches have been comprehensive, and have gone through several years. The selection of sources has been purposeful to answer the research questions. To ensure scientific quality, only peer-reviewed published literature was considered. Reports and 
policy documents were excluded from the review. The review includes information from the chapters of three handbooks (Lumby, Crow \& Pashiardis, 2008; Young et al., 2009; Young \& Crow, 2017), ${ }^{4}$ scientific articles and book chapters with a particular focus on school leadership development, sources based on searches via Google Scholar by applying concepts as: school leadership development, development/preparation, the education of school leaders/principals/managers/administrators/directors, and school heads. The selection of sources was based on reference lists. Only sources in English and Scandinavian languages were included.

The strategy for carrying out the review has been to 1) develop an overview of the literature by reading chapters in handbooks and previous reviews; 2) craft research questions; 3) make decisions about the eras; 4) carry out searches to identify information about the purpose, providers, pedagogies, content, and the organization of the programs, as well as the related concerns and methodologies related to the different eras; 5) analyze the sources with the aid of Gunter and Ribbins' (2003) conceptual framework, and finally; 6) identify strengths and weaknesses and further need of research.

\section{What we know, and how we know it, from 1950 to the present}

This section is divided into three sub-sections: leadership development knowledge of the 1950s, the 1980s, and from 2000 onward. Since there is more research available from the 1980s and 2000, these sections are longer than the section from the 1950s. The sub-section presents what we have learned from research about the purpose, providers, pedagogies, content, and organization of leadership development. Additionally, the sub-sections identify and analyze those underlying concerns and methodologies that might have affected the research.

\section{Leadership development research beginning in the 1950s}

Although the U.S. was virtually alone in providing university-based leadership programs in the 1950s, a few countries outside the U.S. began to introduce such programs at the end of the 1950s and in the 1960s; these countries include Canada, the U.K., and New Zealand (Miklos, 1983). Since 1950, a number of events have affected education programs and research in the U.S. (Taylor et al., 2009); these events include the establishment of research associations and journals as well as the publication of several important books about administration and the Theory Movement.

The purpose and the content. Daniel Griffiths was a central scholar in this movement, and the rationale behind it was that theory could be structured into law as generalizations and testable consequences and that a focus should be placed on operational definitions (Evers \& Lakomski, 1990. Scholars attempted 
to develop a value-free knowledge base for educational programs grounded in hypothetic-deductive methods (Chin, 2003). However, there was no consensus as to whether the need existed for such a knowledge base. The knowledge being passed on in these programs centered mainly on behavior science (Chin, 2003); however, from the 1950s on, attempts were made to broaden the conceptual base of administration ${ }^{5}$ by including issues from the social sciences and humanities (Miklos (1983). The argument at play was that administration was something more than the mere execution of technical tasks. The purpose was to teach the students theories about administration. Attempts were made to encourage students to take courses outside the program as well as to incorporate social science into existing programs. Survey data revealed that only a small proportion of students in Canada and the U.S. enrolled in social science courses outside the departments of administration and educational science. Various social science topics were included in administration programs in Canada and the U.S. as well as in Australia and Britain. Attempts were also made to incorporate the humanities, especially via a focus on moral issues. By the late 1960s, it became evident through surveys that only a few students felt that the content of their programs was based on humanities topics (Miklos, 1983). It also became evident through survey data that the values of the theory movement to a small degree had permeated the thinking and teaching of administration professors.

The pedagogies and the organization. Inspired by social science, inquiry tools were employed to the programs (Chin, 2003). Field-based work was introduced, and discussions and lectures became commonplace in the 1970s. Miklos (1983) refers to survey studies conducted in the U.S., Canada, and Britain, which revealed that innovative structural practices were incorporated into these programs, though not to a revolutionary extent. The period from 1947 to 1985 was called "the behavioral science era" (Murphy, 1998), and the theory movement lost momentum during the 1970s and 1980s (Taylor et al., 2009).

Criticism of the research approaches. Thomas Greenfield was one who engaged in discussions regarding such methodologies in the mid 1970s. Greenfield \& Ribbins (1993) is a collection of Greenfield's views of social reality based on ten of his key papers. One of his arguments was that quantitative research approaches were incapable of addressing the major themes within theory of administration, such as those related to values, will, and ethics. Qualitative and phenomenological approaches were suggested as alternatives when attempting to make sense of the complicated processes of social interaction (Chin, 2003).

In sum: What we have learned about leadership development as a "practice" (cf. Gunter \& Ribbins, 2003) during this era is that universities were the providers of school leadership development. The purpose of these programs was to increase students' knowledge about administration theory, and content was mainly drawn from the behavioral sciences; however, attempts were made to 
include social science and humanities topics in the content. Moreover, lectures, discussions, fieldwork, and the use of inquiry tools became part of the pedagogy and the organization of these programs.

Analysis of the underlying concerns and dominant methodologies that might have affected the research from the 1950s indicates that the research had "instrumental purposes" as well as "descriptive purposes" (cf. Gunter and Ribbins, 2003). The instrumental purposes became visible since researchers were concerned with developing a knowledge base for the teaching which was assumed to become effective for leadership in schools, while descriptive purposes became visible since researchers collected survey data from the students about aspects such as the content and the pedagogies in the programs, and the critical perspective became visible in the critiques of the research approaches.

\section{Leadership development from the 1980s onward}

The role of principals changed dramatically in the 1980s (Hallinger, 2003). One event that influenced the education practices of the U.S. was the publication of a national report entitled "A Nation at Risk" (Gardner, 1983). This report highlighted the failure of the U.S. educational structure and its approaches also to leadership development. Principals went from being responsible for maintaining stability to being responsible for leading change processes in their schools. Furthermore, questions were raised regarding school leaders' ability to lead the change processes necessary for the implementation of educational reforms (Ferrandino, 2001; Grogan \& Andrews, 2002).

The providers and the organization. Previously available exclusively at universities, school leadership development programs began to be offered at several state-sponsored and principal-led centers established in the U.S. during the 1980s. Moreover, several private foundations began to support leadership programs, experiment with cohort groups of students, collaborate across districts, and establish curricula across courses. Several Asian countries established administrative training centers during the 1980s, and several universities in Asian countries began to offer master's degree programs in educational leadership and administration. The U.S. was no longer alone in educating school leaders.

Organizing school leadership development in cohorts ${ }^{6}$, began in the 1950s, but became more common in the U.S. in the end of the 1980s as a response to criticism of the program structures (Grogan et al., 2009). The standard size was $10-25$ students. In the U.S. over $50 \%$ of the programs were organized in cohorts.

During this era, there were several purposes of school leadership development. Because it was considered important for leaders to constructively apply their practical experience, preparation programs were expected to help leaders reflect upon their own practices (Chin, 2003). Such programs also aimed 
at creating social justice leaders and focusing on ethical leadership development (Osterman \& Hafner, 2009), which indicate that the purposes had expanded since the 1950s.

The content. In the 1980s, the U.S. was one of the few countries that required pre-service preparation or certification prior to one's appointment to an administrative position in a school (Hallinger, 2003). While requirements existed for pre-service preparation or certification in the U.S., neither the U.S. nor other countries had established requirements for further leadership development. Focus was placed on the preparation of school leaders rather than on further professional development.

The content of these programs varied, but among the many covered topics were: strategies for communication and decision-making, legal aspects of school management, strategic planning, total quality management, policy analysis, school leadership in instruction and administration, curriculum management and teaching methods, the business management of financial and material resources, strategies for school evaluation, school innovation and development, and creating external relationships with parents, educational authorities, and special interest groups (Chin, 2003, p. 61), which indicate that the content had expanded since the 1950s.

The pedagogies. Scholars argued that there was a need for more relevant teaching methods (Taylor et al., 2009), and efforts to connect the preparation of school leaders to the practices of school leadership became a central issue (Chin, 2003). Problem-based learning (PBL), simulations, and various apprenticeships were established in an effort to enhance the connection between these programs and school practices. Such pedagogical methodologies - as well as many others involving film, video and multimedia technology - and case methods became commonplace beginning in the early 1990s (Taylor et al., 2009). Taylor et al. (2009, p. 326) presented what they called a "learning and teaching continuum" which placed some activities to involve minimal/none, peripheral of full students participation, being close to the classroom or to students' workplaces. Many students reported they profit more from authentic, field-based pedagogy, as opposed to from lectures and discussions. However, as Taylor et al. argues, there were survey studies and empirical research, but the findings were often based on small-scale studies with weak analyses that rarely measure long-time results of the different pedagogies. The research was heavily based on students' perceptions.

The criticism of the research. Beginning in the 1980s, scholars positioned within critical theory, postmodernism, and value theory, engaged in criticism of positivistic research approaches to educational administration. The tradition of school effectiveness (Creemers, 1996; Hallinger \& Heck, 1999; Mortimore \& Whitty, 2000; Sammons, Hillman \& Mortimore,1995) was criticized for its role in developing laws for leadership (Smyth, 1989). Critics argued that the phenomenon of administration is social in nature (Evers \& Lakomski, 1990) and 
that the subjective nature of this phenomenon makes it impossible to document through natural science. The period from 1986 onward was referred to as the "dialectic era" (Murphy, 1998), or an "era of globalization"7 (Hallinger, 2003). During this period, Gunter (1995) contrasted and theorized the so-called "quickfix" training method, which focused on "how to do it". Their engagement might have had a greater influence on methodologies than on practice (Chin, 2003). The researchers were first and foremost concerned with issues of ontology and epistemology as well as with conceptual clarifications-or what Gunter and Ribbins (2003) referred to as "conceptual purposes". Not many studies have been positioned with a critical perspective, but Møller's (1995) was inspired by critical hermeneutics. Data were collected from observation, logs, and interviews. Møller examined what happens when school leaders were offered possibilities for systematic observation, supervision and assessment of educational leadership in practice. She found that having practice as a departure point of learning seems to lead to a greater awareness of their roles and functions as school leaders. However, the school leaders' reflections were first and foremost dominated by an internal focus. Only to a small degree, comments on ideologies in society and policy contexts were included in their reflections. According to the principals, external supervisions played an important role in their learning outcomes, but the theoretical and practical expertise of the external facilitator were important premises to succeed.

In sum: What we have learned about school leadership development from the 1980s onward is that a number of countries began to educate school leaders. Furthermore, universities were no longer the sole providers of such knowledge: several public and private institutions began to offer school leadership programs. In addition, their contents expanded when new topics were added to the list, and the pedagogies, as well as the structures, were especially related to organizing the students into cohorts.

An analysis of the underlying concerns and dominant methodologies that might have affected research from the 1980s indicates that the research still had "instrumental purposes" (cf. Gunter \& Ribbins, 2003), since scholars from the school effectiveness tradition were engaged in developing laws for effective leadership. The research also had "descriptive purposes" since the research described many aspects of school leadership development such as pedagogies and contents. The research field was expanded to include research with "critical purposes" and "conceptual purposes", albeit not to a large degree.

\section{Leadership development from 2000 onward}

Based on interviews, surveys, and the analysis of documents, we know that several countries in North America, Europe, Asia, Australia, and New Zealand began to offer extensive, comprehensive programs for the preparation and development of school leaders from 2000 onward (Hallinger, 2003; Huber, 2010). One example is England. The National College for School Leadership 
(the National College) was established to address the preparation of all aspiring school leaders. ${ }^{8}$ Another example is Canada's province of Ontario, which has aimed at improving leadership on a large scale (Leithwood et al., 2011).

After the year 2000, there were additional expectations for school leaders as a result of accountability pressures, often from outside education, to turn around schools, leading to data use, teacher evaluations, and a focus on social justice, diverse learners, and student results (Cobb, Weiner \& Gonzales, 2017). It became a pressure to cope with such expectations in the education of school leaders.

The purpose and the organization. Moreover, there existed a wide variety of ways that school leadership development was organized in Europe. Based on an analysis of documents, Møller and Schratz (2008) found that in most countries the central government has a strong influence on the provision of leadership training. In 2008, Norway and Denmark had a more decentralized training provision, which was governed by regional stakeholders who collaborated with professional organizations. The authors indicate the situation in the two countries may change as a result of discussions about the balance between political versus professional power.

Learning to become a school leader is not a one-time happening, but a career-long process (Earley \& Weindling, 2004). Huber (2010) found there is a trend towards requiring participation in time-consuming programs as a preparation for leadership responsibilities in schools. The combination of course-based learning at colleges and universities with experience-based learning in workshops and at the workplace was also identified in the study. Research also noted the trend of extending short courses into extensive programs and distinguishing between different phases in school leaders' careers when designing opportunities to learn.

When it comes to the purposes of the programs, Huber (2010) revealed differences related to whether the programs are oriented towards tasks, competencies, the school's development, cognition, visions, and/or values. He found it has become a trend to be more explicit concerning the aims and objectives of programs.

The content and the pedagogies. Like the previous era, a variety of topics constitute the content of school leadership development. In many countries, there are trends toward focusing on the schools' core purposes for student learning, team development, and improving each individual school that students attend (Huber, 2010). Bush and Jackson (2002) found, based on visits and survey data, that Canada and England had a shared focus on organizational, transformational, and instructional leadership as well as professional development, finance, and curriculum. With increasing emphasis on accountability, there might be a specific framework for content, which is decided on nationally. This is the case in the US, where standards were released in 1996 and revised in 2008 and 2016 (Carpenter, Paredes \& Lindle, 2017). 
Using schools as clinical faculties has become common in so-called experience-based learning, in contrast to more course-based learning (Huber, 2011). Experience-based learning may imply extensive internships and shadowing and project work. After 2008, pedagogical approaches such as reflections, focused observations, field-based experiences, cohorts, PBL, continued to be used (Byrne-Jimenéz et al., 2017, p. 182). In addition, andragogical methods ${ }^{9}$ became common, for example, cultural autobiographies, equity audits, life histories, diversity presentations and panels, reflective analyses, journals, etc. Nevertheless, there is a lack of empirical research on the pedagogical approaches to school leadership development, although some examples exist. Aas and Flückiger (2016) examined the steps used in group coaching processes from interviews and observations in school leadership programs in Norway and Australia to identify critical aspects of the coaching role. Their findings suggest that the coaching role requires a unique set of skills.

Although we are living in a technology-rich world and school leaders are integrating technologies into schools, the role of technologies in school leadership programs is limited. Dexter, Richardson, \& Nash, 2017) reviewed syllabi in state preparation programs in the US. Beyond using technology for management, Dexter et al. found the programs rarely offered coursework on technology issues. Examples of the use of Google Docs, wikis, synchronic tools, digital storytelling, digital reflections, and moving course content online are appearing. Most of the research articles have focused on tool usage, the faculty experience, or students' perceptions rather than examining the impact of digital technology empirically. Jensen and Møller (2013) examined how professional learning is played out empirically in the interactions among members of a school improvement team in a Norwegian context by paying special attention to the role of video clips for teaching as the departure for the professional development of principals. The findings suggest that video clips of teaching practices stimulate engagement among team members and, hence, mediate professional learning processes beyond the situations presented in the workshops, as well as concern how to understand and improve teaching practices. External facilitation seemed crucial for anchoring the analysis theoretically and for highlighting implications for leadership in the workshops.

Causal perspectives. A range of theoretical models have been developed in recent decades to explain the causal relationships between leadership and student learning. In these studies, school leadership development is one of several indirect factors, often derived from quantitative approaches (Firestone \& Riehl, 2005; Hallinger \& Heck, 2010; Leithwood \& Jantzi, 2008; Mulford \& Silins, 2003; Simkins et al., 2009). More extensive studies have focused on the effects of the programs. Among those studies is Orr and Barbers' (2007) examination of two university-district partnerships based on a survey and program-feature documentation. They found that a standards-based curriculum as well as broader and more intensive internships influenced the students' 
perceptions of gains in skills, career intentions, and advancements in their leadership positions. Darling-Hammond et al.'s (2010) study was grounded in an empirically based inquiry. They argue their findings support previous findings from adult learning related to creating a standards-based curriculum, highly qualified faculty, strong partnership with school districts, cohort groups that create an opportunity for collaboration in practice learning, action research, and field-based projects. It is not made explicit what constitute the data material from those findings.

Critical perspectives. Additionally, after 2000, a few scholars continued to examine school leadership development from a critical perspective. Gunter and Forrester (2009), for example, investigated the relationship between the state and civil society by using the National College for School Leadership as a case study. Based on primary documentation and interview data, they found this was an example of institutional governance in which the government had control over the education of school leaders by using private advisors and consultants to generate approved policy ideas and deliver reform strategies.

In sum: What we have learned about school leadership development from the 2000s is that the ways in which school leadership development is organized, varies regarding to centralization, decentralization, professionalization, and politicization, although in most countries the central government has a strong influence on the provision of leadership training. There is now more knowledge about aspects of the use of cohort models. The purposes of school leadership development have also expanded as well as the contents, which in some countries are manifested as standards. A range of new pedagogies are identified in addition to previous pedagogies; among the new pedagogies are a variety of digital technologies.

An analysis of the underlying concerns and dominant methodologies that might have affected research from 2000, indicates that all six typologies of Gunter and Ribbins (2003) are present in the research on school leadership development, although to a different extent. Surveys and interviews are still dominant, although researchers are beginning to use and support the research with other methodologies. From 2000 evaluative perspectives gained more attention. The next section discusses the strength and weaknesses of the existing research.

\section{Strengths and weaknesses of the research}

The strengths. The analyses have shown that the knowledge provinces being engaged in researching school leadership development from the 1950s have expanded. Because the different "knowledge provinces" are concerned with illuminating different aspects of school leadership development as "practice", this matter might be considered having strengthened school leadership 
development as a field of research. Among those aspects are the purposes of the programs, the providers, the content, the pedagogies, and the structure. Today we know more about what kinds of school leadership that are offered ("the what"). It has also confirmed that the researchers use different methodologies, which enables to illuminate different aspects of school leadership development. While survey was a dominating methodology from the 1950s, interviews were introduced as promising methodology in the 1980s. Later, the review has revealed that researchers have used additional methodologies such as document analyses, observation, case methodologies, audio and video recordings etc. Three handbooks on leadership development (cf. Lumby et al., 2008; Young et al., 2009; Young \& Crow, 2017) are a visible expression of the field having expanded enormously since the 1950s.

Despite the extensive knowledge of what kind of leadership development is offered (the "what"), there are some weaknesses of the research that are important to discuss when identifying implications for further research as well as further development of school leadership development as practice. In the following, I present six different weaknesses in the existing research.

A lack of research on leadership development as "actual practices". The first aspect of such weaknesses was mentioned above, regarding the dominant use of surveys and interviews from the 1950s onwards. One cannot take for granted that what students, educators, faculty members, providers, etc., report in interviews and surveys about the different aspects of school leadership development reflect how leadership development proceeds and develops in what Bryman (2012) calls "natural settings" or what Miklos (1983) terms "actual settings". Individual responses may contribute to our understanding of how leadership development is retrospectively, individually experienced, but it may not produce knowledge about how leadership development proceeds and develops, which is important when evaluating existing programs and developing new ones. As Miklos (1983, p.154) argues, "It is much easier to document what the beliefs about preparation have been over a period of time than it is to describe "actual practice"."

Lack of research on aspects of leadership development in social settings. Second, the review has shown that leadership development often takes place in social settings, cohort groups, seminar groups, teams, etc. (cf. Grogan et al., 2009; Huber, 2011). While videos in classroom research have contributed with knowledge about aspects of teaching and learning classroom activities (Klette, 2007), video research has definitely not dominated the research on school leadership development. Video data may capture the situatedness of school leadership development, which surveys and interviews do not allow. However, video-recordings might be very time consuming and demanding with respect to methodologies and the use of technical equipment. The problem of timeconsuming methodologies is that individual researchers do not manage to collect data from many cases. It has been a recurring problem in the present research 
field that the field is dominated by many small case-studies (cf. Lumby, Pashiardis \& Crow, 2008; Crow et al., 2009; Young \& Crow, 2017). However, it should be possible, similar to the classroom studies, to design larger studies which can move the field forward beyond what is possible through self-report alone. If so, the unit of analysis needs to be expanded beyond individual responses to obtain knowledge about issues-such as patterns of discursive interactions, social dynamics, and learning processes - in which many actors are participating.

A lack of research on development across working contexts, professions, and positions: A third shortcoming is that the research does not sufficiently reflect the different working contexts, professions, and positions in play when organizing school leadership development. Within a cohort, for example, students may come from varying schools and districts (cf. Barnett \& Muse, 1993). As the reviews shows, from the 1980s the number of providers has increased. This may imply new types of collaborations. The actors may have disparate positions, even professions, which may influence how leadership development evolves in the different settings, especially when it comes to learning and development. Researchers being positioned within research on workplace learning and higher education (see for example: Akkerman \& Bakker, 2011; Edwards, 2010; Engeström, 1987) have extensively researched the gains as well as the strains of collaborating across working contexts, professions, and positions. Such issues are, to a small degree, touched upon in the research literature on school leadership development. There is also the need for theoretical frameworks allowing for the explanation of processes that evolve when actors from different contexts, professions, and positions are being educated. Network theories, theories of boundary-work, and situated learning are examples of theories, which may illuminate aspects of school leadership development that have not gained much attention.

A lack of research across timescales. The fourth aspect to take into consideration is that the research literature on leadership development reflects only to a minor degree that leadership development is now organized in modules, in workshops, and through shadowing for different lengths of time, often in parallel with work in the schools to a small degree, rather than a onetime happening (cf. Crow et al., 2008; Huber, 2011). These are aspects that make school leadership demanding to research empirically, not at least because school leadership development may take place close to the workplaces and/or close to the universities. An overall purpose of school leadership development is to educate school leaders for leadership in schools. The students might work when taking courses in school leadership development. Consequential longitudinal data and decisions regarding timescales and contexts may be necessary when analyzing the data. Increasingly, many researchers argue that longitudinal studies would permit us to know how leadership programs 
influence ongoing leadership practices and student learning (Jacobson \& Bezzina, 2008; Taylor et al., 2009; Hallinger \& Heck, 2010).

A lack of qualitative research on causality. The fifth weakness is related to the need of making causal explanations when researching school leadership development. As already reported, scholars have been concerned with explaining the causal relationships between leadership and student learning, where school leadership development is one of several indirect factors, often derived from quantitative approaches based on surveys (cf. Firestone \& Riehl, 2005; Leithwood \& Jantzi, 2008). Documenting causality is not restricted to quantitative designs. Qualitative researchers may also contribute with analyses, albeit in different ways. In so-called qualitative and process-oriented research the argument is that causation can be observed and reconstructed as real sequences of events (Engeström, 2011). Historical methods, narrative evidence, observations, and recordings are used to reveal chains of events and causation. Cultural historical theories provide an analytic framework for examining causation in real chains of events. Such approach might be relevant when studying school leadership development, because it allows analyses of why some activities become conducive for changes in leadership practices in schools.

A lack of attention to the role of tools and the theoretical lenses. Sixth, at least from the 1950s, different approaches and tools have been used to make leadership development authentic and relevant (Taylor, et al 2009, ByrneJiménez et al., 2017; Dexter et al., 2017). The tools are manifested as physical, conceptual, as well as virtual. If and perhaps how the different tools may mediate learning has thus far gained little attention. One cannot take for granted that the tools mediate what is intended; because the tools may mediate something else. For example, faculty members may introduce a specific article (an artifact) that they think will help the students solve a task where the students are supposed to describe the differences between paradigms. In interviews, students may argue that the article helped them solve the task. Through empirical analysis, the researcher may discover that the artifact did not mediate in accordance with the faculty member's expectations but in an unintended way because the students used the article to back up normative rather than analytic arguments. Consequentially, more knowledge about those processes is needed to develop school leadership as practices in the future. Such an approach requires the inclusion of tools in the unit of analyses, as well as an analysis of interactions with the tools. In addition, there is a need for a theoretical framework paying attention to the role of tools in human functioning. Since Vygotsky's (1986) work on mediation, the role of tools in human functions, collective settings, and boundary settings has been extensively theorized within a sociocultural tradition. The objects of sociocultural studies are events, activity, and practice (Daniels, 2008). Cultural historical activity theory (CHAT) is one of several theories focusing on socio-materiality (Fenwick, Edwards, \& Sawchuk, 2011). The artifacts are not only something "non-human”, but they 
also shape the activity. In other words: there is a need for the researcher to engage with "conceptual purposes" (cf. Gunter \& Ribbins, 2003) to theorize the use of tools in school leadership development.

In sum: This review has shown that research with "critical purposes" and “conceptual purposes” (cf. Gunter \& Ribbins, 2003) has not dominated the research of school leadership development. I will argue that there is a need for engagement from "critical perspectives" to reveal critical aspects of school leadership development related to power structures, gender aspects etc. In addition, there is a need of "theorizing" about school leadership development to compensate for the fact that the field is rather under-theorized (cf. Lumby et al., 2008).

There is a need of paying more attention to the situatedness of school leadership development ("the how"), which may imply the introduction of a seventh research typology where researchers are engaged in research processes to document and explain aspects of situated activities. Because all methodologies have weaknesses, supporting the analyses with other methods might be beneficial.

\section{Concluding remarks}

The purpose of the present article was to gain an enriched understanding of what we know about school leadership development and how we have come to know it and to use this understanding as a foundation for discussion regarding the implications for further research on school leadership development. To meet this purpose, various sources such as handbooks and scientific journals were accessed. The aims were to present an international literature review of school leadership development research that encompasses a period from the 1950s to the present, to identify the dominant research methodologies and concerns, and to discuss the strengths and weaknesses of the existing research to encourage dialogues about further research on school leadership development.

When examining what we have learned about school leadership development from the 1950 to the present day, the findings suggest much expansion of the purposes, providers, pedagogies, content, and the way school leadership development is organized.

In the identification of the underlying concerns and dominant methodologies that might have affected the "processes" of research in the different "research products", when examining school leadership development as "practice", the findings suggest that all six "knowledge provinces" (cf. Gunter and Ribbins, 2003) are present. While "instrumental provinces" and "descriptive research provinces" were engaged from the 1950s, "critical research provinces" became engaged from mid 1970s. "Conceptual research provinces" became engaged from the 1980s, albeit not to a large degree, and "evaluative provinces" from 
2000. There is a need of engagement from researchers who are concerned with illuminating aspects of the situatedness of school leadership development, i.e. how school leadership development evolves, how the tools may mediate learning, and what is being accomplished in school leadership development ("the how"). In addition, there is a need of more research with "conceptual purposes", since the field of research is rather under-theorized (cf. Lumby et al., 2008), and a need of more research with "critical purposes" to examine aspects related to power, gender etc. ("the why"), when several actors are involved in providing school leadership development.

The review has some limitations. First, it is a limitation that English sources have dominated the reveiw. Second, it is a limitation that there are several other sources that could be added to the review. However, that would be beyond the scope of the present review. Nevertheless, it might be argued the research has not kept pace with all changes in the "practice" of school leadership development. The implications of the literature review is to pay attention to what we have learned about school leadership development, the dominant concerns and methodologies, as well as about the strengths and limitations of the research when developing existing programs and new programs in the future.

\section{References}

Aas, M., \& Flückiger, B. (2016). The role of a group coach in the professional learning of school leaders. Coaching: An International Journal of Theory, Research and Practice, 9(1), 38-52.

Akkerman, S. F., \& Bakker, A. (2011). Boundary crossing and boundary objects. Review of Educational Research, 81(2), 132-169.

Barnett, B. G., \& Muse, I. D. (1993). Cohort groups in educational administration: Promises and challenges. Journal of School Leadership, 3(4), 400-415.

Brundrett, M. (2001). The development of school leadership preparation programmes in England and the U.S.A: A comparative analysis. Educational Management Administration \& Leadership, 29(2), 229-245.

Bryman, A. (2012). Social research methods. Oxford, UK: Oxford University Press.

Bush, T., \& Jackson, D. (2002). A preparation for school leadership international perspectives. Educational Management Administration \& Leadership, 30(4), 417-429.

Byrne-Jiménez, M., Gooden, M. A., \& Tucker, P. D. (2017). Facilitation learning in leadership preparation: Limited research but promising practices. In M. D. Young \& G. Crow (Eds.), Handbook of research on the education of school leaders (pp. 173-201). New York, NY: Routledge.

Carpenter, B. W., Paredes, S. M. \& Lindle, J. (2017). The political and economic contexts of educational leadership preparation. In M. D. Young \& G. M. Crow (Eds.), Handbook of research on the education of school leaders (pp. 40-52). New York, NY: Routledge.

Chin, J. (2003). Reconceptualizing administrative preparation of principals: epistemological issues and perspectives. In P. Hallinger (Ed.), Reshaping the landscape of school leadership development: A global perspective (pp. 53-67). Groningen, The Netherlands: Swets \& Zeitlinger Publishers. 
Cobb, C. D., Weiner, J. M., \& Gonzales, R. (2017). Historical trends and patterns in the scholarship on leadership preparation. In M. D. Young \& G. M. Crow (Eds.), Handbook of research on the education of school leaders (pp. 15-39). New York, NY: Routledge.

Creemers, B. (1996). The school effectiveness knowledge base. In D. Reynolds, R. Bollen, B. Creemers, D.Hopkins, L. Stoll, \& N. Lagerweij (Eds.), Making Good Schools: Linking School Effectiveness and Improvement (pp.36-58). London, UK: Routledge.

Crow, G. M., Lumby, J., \& Pashiardis, P. (2008). Introduction: Why an international handbook on the preparation and development of school leaders? In J. Lumby, G. Crow \& P. Pashiardis (Eds.), International handbook on the preparation and development of school leaders (pp. 1-17). New York, NY: Routledge.

Crow, G. M., Young, M. D., Murphy, J. \& Ogawa, R. T. (2009). Conclusion. In M. D. Young, G. M. Crow, J. Murphy, \& R. T. Ogawa (Eds.). Handbook of research on the education of school leaders (pp. 535-545). New York, NY: Routledge.

Daniels, H. (2008). Vygotsky and research. New York, NY: Routledge.

Darling-Hammond, L., Meyerson, D., La Pointe, M., \& Orr, M. T. (2010). Preparing principals for a changing world: lessons from effective school leadership programs. San Francisco, CA: Jossey-Bass.

Davis, S., Darling-Hammond, L., LaPointe, M., \& Meyerson, D. (2005). School leadership study: Developing successful principals (Review of Research). Stanford, CA: Stanford Educational Leadership Institute.

Dempster, N., Lovett, S., \& Flückiger, B. (2011). Strategies to develop school leadership: A select literature review. Retrieved from http://www.aitsl.edu.au/docs/defaultsource/clearinghouse/strategies-to-developschoolleadership

Dexter, S., Richardson, J. W., \& Nash, J. B. ( 2017). Clinical practice in educational leadership. In M. D. Young \& G. M. Crow (Eds.), Handbook of research on the education of school leaders (pp. 202-228). New York, NY: Routledge.

Edwards, A. (2010). Being an expert professional practitioner: The relational turn in expertise. Dordrecht, Netherlands: Springer.

Earley, P., \& Weindling, D. (2004). Understanding school leadership. Sage.

Engeström, Y. (1987). Learning by expanding: An activity-theoretical approach to developmental research. Helsinki, Finland: Orienta-Konsultit.

Engeström, Y. (2011). From design experiments to formative interventions. Theory \& Psychology, 21(5), 598-628.

Evers, C. W., \& Lakomski, G. (1990). Knowing educational administration: Contemporary methodological controversies in educational administration research. New York, NY: Pergamon Press.

Ferrandino, V. L. (2001). Challenges for 21st-century elementary school principals. Phi Delta Kappan, 82(6), 440.

Firestone, W. A., \& Riehl, C. (Eds.). (2005). A new agenda for research in educational leadership. London, UK: Teachers College Press.

Gardner, D. P. (1983). A Nation At Risk: The Imperative For Educational Reform. An Open Letter to the American People. A Report to the Nation and the Secretary of Education. U.S. Department of Education. Washington, D.C.

Grant, M. J., \& Booth, A. (2009). A typology of reviews: an analysis of 14 review types and associated methodologies. Health Information \& Libraries Journal, 26(2), 91-108.

Greenfield, T., \& Ribbins, P. (1993). Greenfield on educational administration: Towards a humane science. New York, NY: Routledge.

Grogan, M., \& Andrews, R. (2002). Defining preparation and professional development for the future. Educational Administration Quarterly, 38(2), 233-256. 
Grogan, M., Bredeson, P. V., Sherman, W. H., Preis, S., \& Beaty, D. M. (2009). The design and delivery of leadership preparation. In M. D. Young, G. M. Crow, J. Murphy, \& R. T. Ogawa (Eds.), Handbook of Research on the Education of School Leaders (pp. 395-415). New York, NY: Routledge.

Gunter, H. M. (1995). Jurassic management: chaos and management development in educational institutions. Journal of educational administration, 33(4), 5-20.

Gunter, H. M., \& Forrester, G. (2009). School leadership and education policy-making in England. Policy studies, 30(5), 495-511.

Gunter, H. M., \& Ribbins, P. (2003). The field of educational leadership: Studying maps and mapping studies. British Journal of Educational Studies, 51(3), 254-281.

Hallinger, P. (2003). The emergence of school leadership development in an era of globalization: 1980-2002. In P. Hallinger (Ed.), Reshaping the landscape of school leadership development: A global perspective (pp. 3-22). Lisse, The Netherlands: Swets \& Zeitlinger Publishers.

Hallinger, P., \& Heck, R. (1999). Can leadership enhance school effectiveness? In T. Bush, L. Bell, R. Bolam, R. Glatter, \& P. Ribbins (Eds.), Educational Management: Redefining Theory, Policy and Practice (pp. 178-190).

Hallinger, P., \& Heck, R. H. (2010). Collaborative leadership and school improvement: Understanding the impact on school capacity and student learning. School Leadership and Management, 30(2), 95-110.

Huber, S. G. (2010). Preparing school leaders - international approaches in leadership development. In S. G. Huber (Ed.), School leadership - international perspectives (pp. 225-251). Netherlands: Springer.

Huber, S. G. (2011). Leadership for learning-learning for leadership: The impact of professional development. In T. Townsend \& J. MacBeath (Eds.), The international handbook of leadership for learning (pp. 831-853). New York, NY: Springer.

Jacobson, S. L. \& Bezzina, C. (2008). Effects of leadership on student academic/affective achievement. In J. Lumby, G. Crow \& P. Pashiardis (Eds.), International handbook on the preparation and development of school leaders (pp. 1-17). New York, NY: Routledge.

Jensen, R., \& Møller, J. (2013). School data as mediators in professional development. Journal of Educational Change, 14(1), 95-112.

Klette, K. (2007). Trends in research on teaching and learning in schools: Didactics meets classroom studies. European Educational Research Journal, 6(2), 147-160.

Leithwood, K., \& Jantzi, D. (2008). Linking leadership to student learning: The contributions of leader efficacy. Educational Administration Quarterly, 44(4), 496-528.

Leithwood, K., Reid, S., Pedwell, L., \& Connor, M. (2011). Lessons About Improving Leadership on a Large Scale: From Ontario’s Leadership Strategy. In T. Townsend \& J. MacBeath (Eds.), International handbook of leadership for learning (pp. 337-353). Springer Netherlands.

Lumby, J., Crow, G. M., \& Pashiardis, P. (2008). International handbook on the preparation and development of school leaders. New York, NY: Routledge.

Lumby, J. Pashiardis, P. \& Crow, G. M. (2008). Epilogue. In J. Lumby, G .M. Crow \& P. Pashiardis (Eds.), International handbook on the preparation and development of school leaders (pp. 465-467). New York, NY: Routledge.

Miklos, E. (1983). Evolution in administrator preparation programs. Educational Administration Quarterly, 19(3), 153-177.

Mortimore, P., \& Whitty, G. (2000). Can school improvement overcome the effects of disadvantage? University of London, Institute of Education.

Mulford, B., \& Silins, H. (2003). Leadership for organizational learning and improved student outcomes-What do we know? Cambridge Journal of Education, 33(2), 175-195. 
Murphy, J., \& Hallinger, P. (1992). The principalship in an era of transformation. Journal of Educational Administration, 30(3).

Murphy, J. (1998). Preparation for the school principalship: The United States' story. School Leadership and Management, 18(3), 359-372.

Murphy, J., \& Forsyth, P. B. (1999). Educational administration: A decade of reform. Thousand Oaks, CA: Corwin Press.

Møller, J. (1995). Rektor som pedagogisk leder i grunnskolen: i spenningsfeltet mellom forvaltning, tradisjon og profesjon [The school principal as an educational leader in compulsory school: tensions between administration, tradition and profession]. Dr.polit dissertation, Department of Education, University of Oslo.

Møller, J., \& Schratz, M. (2008). Leadership development in Europe. In J. Lumby, G. Crow, \& P. Pashiardis (Eds.), International handbook on the preparation and development of school leaders (pp. 341-366). New York, NY: Routledge.

Orr, M. T., \& Barber, M. E. (2007). Collaborative leadership preparation: A comparative study of partnership and conventional programs and practices. Journal of School Leadership, 16(6), 709-739.

Osterman, K. F., \& Hafner, M. M. (2009). Curriculum in Leadership Preparation. In M. D. Young, G. M. Crow, J. Murphy, \& R. T. Ogawa (Eds.), Handbook of Research on the Education of School Leaders (pp. 269-317). New York, NY: Routledge.

Sammons, P., Hillman, J. \& Mortimore, P. (1995). Key characteristics of effective schools: A review of school effectiveness research, International School Effectivenes \& Improvement Centre, Institution of Education, University of London, London, UK.

Simkins, T., Coldwell, M., Close, P., \& Morgan, A. (2009). Outcomes of in-school leadership development work: A study of three NCSL programmes. Educational Management Administration \& Leadership, 37(1), 29-50.

Smyth, J. (1989). Critical perspectives on educational leadership. Philadelphia, PA: Falmer Press.

Taylor, D. L, Cordeiro, P., \& Chrispeels, J. H. (2009). Pedagogy. In M. D. Young, G. M. Crow, J. Murphy, \& R. T. Ogawa (Eds.), Handbook of research on the education of school leaders (pp. 319-369). New York, NY: Routledge.

Young, M. D., Crow, G. M., Murphy, J., \& Ogawa, R. T. (2009). Handbook of research on the education of school leaders. New York, NY: Routledge.

Young, M. D. \& Crow, G. M. (2017). Handbook of research on the education of school leaders. New York: Routledge.

Vygotsky, L. S. (1986). Thought and language. Cambridge, MA: MIT Press.

\footnotetext{
${ }^{1}$ The approach to make a "literature review" is explained more in detail in Section 3.

2 The three remaining typologies are "the producers", "the positions", and "the perspectives".

${ }^{3}$ The search method may or may not include comprehensive searching, quality assessment. It is typically narrative, and may be chronological, conceptual, and thematic (Grant \& Booth, 2009, p. 97).

${ }^{4}$ The second handbook refers to a U.S. context, while the other two refer to an international context.

${ }^{5}$ The subject was called “administration” in the U.S. Later the programs were called leadership programs (Taylor et al., 2009).

${ }^{6}$ A cohort is defined as "a group of students who begin and complete a program of studies together, engaging in a common set of courses, activities and/or learning experiences” (Barnett \& Muse, 1993, p. 401).

${ }^{7}$ Hallinger used this term for the period from 1980.

${ }^{8}$ In 2013 NCSL was merged with the Teaching Agency. The new name was the National College for Teaching and Leadership.

${ }^{9}$ Pedagogies for adults.
} 